\title{
Pengembangan Metode Serbuk Daun Suji (Pleomele angustifolia N.E.Br) sebagai Identifikasi Sidik Jari Laten
}

\author{
Sri Adelila Sari ${ }^{*}{ }^{*}$, Desi Heriyanti Nasution ${ }^{1}$ \\ ${ }^{1}$ Program Studi Kimia, Jurusan Kimia, Fakultas Matematika dan Ilmu Pengetahuan Alam, Universitas
} Negeri Medan, Sumatra Utara, Indonesia

\begin{abstract}
Corresponding Author: Sri Adelila Sari

sriadelilasari@unimed.ac.id

Received: February 2021 Accepted: August 2021 Published: September 2021

CSri Adelila Sari et al. This is an open-access article distributed under the terms of the Creative Commons Attribution License, which permits unrestricted use, distribution, and reproduction in any medium, provided the original author and source are credited.
\end{abstract}

\begin{abstract}
Fingerprint is a technology that can be used to identify a person. The dusting method is most often used on latent fingerprints because it is relatively easy and simple. However, the composition of the ingredients used in latent fingerprint powder is toxic and can be hazardous to health. This research was carried out using a new natural powder from Suji leaf as a simple, non-toxic, and cheaper. Suji leaf powder produces a green color that comes from the chlorophyll compounds contained in it. This chlorophyll compound will bind to alanine to identify latent fingerprints. The particle sizes used in this study were of 60-200 mesh. The results found that the particle sizes of 100 and 200 mesh provided good green contrast and clear visualization of the fingerprint patterns. Meanwhile, at the particle size of 60 and 80 mesh, it was found that the results were not clear visualized. The highest percentage of fingerprint patterns based on blood group, gender and ethnicity was found in form of loops. The percentage of fingerprint patterns formed based on the highest was of $\mathrm{O}$ 31.1; $\mathrm{B}$ 12.2; $\mathrm{AB}$ 8.8; and $\mathrm{A} 6.6$ percent. The highest percentage of fingerprint patterns formed by gender were of 45.5 for women and 13.3 percent for men. The highest percentage of fingerprint patterns formed by ethnicity were Malay 21.1, Batak 20, and Javanese 17.7 percent.
\end{abstract}

Keywords: development, Suji leaf, dusting method, latent fingerprint

\section{Pendahuluan}

Sidik jari merupakan identitas diri seseorang yang bersifat alamiah, tidak berubah, dan tidak sama pada setiap orang. Sidik jari juga merupakan salah satu teknologi yang dapat digunakan untuk mengidentifikasi seseorang[1]. Prinsip kerja serbuk pengambilan sidik jari adalah interaksi atau melekatnya serbuk secara mekanik dengan komponen sidik jari laten (air dan lemak) pada suatu permukaan. Mekanisme melekatnya serbuk pada sidik jari dapat terjadi melalui dua mekanisme. Mekanisme pertama adalah penempelan bahan dasar serbuk yang bersifat inert pada timbunan lemak dari sidik jari. Mekanisme kedua adalah terjadinya proses melarutnya komponen timbunan sidik jari dengan senyawa tertentu sehingga menghasilkan perubahan warna[2].

Pengembangan sidik jari dengan serbuk didasarkan atas daya rekat serbuk dengan air yang terkandung dalam sidik jari laten tersebut. Serbuk hanya digunakan untuk 
mengembangkan sidik jari laten pada permukaan benda yang tidak menyerap keringat (tidak berpori) seperti kaca, porselen, permukaan yang dipernis/dipoles/dicat dan lain-lain ${ }^{[3]}$.

Beberapa penelitian mengenai sidik jari laten telah dilakukan, antara lain visualisasi sidik jari laten menggunakan bahan herbal yaitu kunyit (Curcuma longa) dengan menggunakan metode serbuk. Hasil yang diperoleh pada serbuk kunyit kering memberikan kontras yang rendah dengan warna kuning. Hasil penelitian ini menunjukkan bahwa bentuk sidik jari yang diperoleh dari 30 sampel memiliki pola: radial loop sebanyak $10 \%$, ulnair loop sebanyak $70 \%$, twinted loop sebesar $3.3 \%$ dan plain whorl sebanyak $16.6 \%{ }^{[4]}$. Identifikasi sidik jari laten dengan menggunakan metode serbuk gambir. Hasil penelitian menunjukkan bahwa sidik jari yang terbentuk berwarna kecoklatan dan memberikan hasil dengan kontras warna yang jelas menggunakan ukuran serbuk 100 dan 200 mesh[5]. Pengembangan visualisasi sidik jari laten menggunakan bahan alam yaitu ubi jalar ungu (Ipomoea batatas L. poiret) menggunakan metode serbuk. Hasil penelitian metode dusting serbuk ubi jalar ungu sidik jari yang terbentuk berwarna ungu kecoklatan dan memberikan hasil dengan kontras warna yang jelas dengan menggunakan serbuk ukuran 100 dan 200 mesh[6]. Penelitian lain menggunakan serbuk multani mitti sebagai pengembangan sidik jari laten pada delapan permukaan yang berbeda dengan jangka waktu enam hari. Hasil penelitian menunjukkan bahwa cetakan yang dikembangkan pada permukaan gelap memberikan kontras yang baik dan lebih jelas dengan serbuk tersebut ${ }^{[7]}$. Sidik jari dapat disajikan pada sembilan permukaan yang berbeda bergantung kepada jenis serbuk yang digunakan dan cetakan laten yang disimpan (sebum dan keringat) ${ }^{[8]}$.

Saat memilih komposisi serbuk yang perlu dipastikan bahwa bahan tersebut tidak berinteraksi secara kimiawi dengan permukaan sidik jari laten. Serbuk yang dipilih harus memberikan kontras warna terbaik ke permukaan. Beberapa substrat kimia yang digunakan dalam serbuk sidik jari beracun dan berpotensi membahayakan kesehatan ${ }^{[4]}$. Penelitian tentang penggunaan perak nitrat sebagai bahan untuk mendeteksi sidik jari laten juga telah dilakukan, dimana konsentrasi molar yang digunakan berkisar antara 0.001 hingga 0.1 M. Kualitas dan stabilitas sidik jari yang dihasilkan pada kertas atau substrat berpori masing-masing menggunakan $\mathrm{AgNO}_{3}$ dan AgNPs ditemukan stabil selama lebih dari satu bulan $[9],[10]$. Pengembangan sidik jari putih pada latar belakang yang lebih gelap telah dilakukan. Salah satunya dengan melarutkan bahan kimia pada permukaan kertas termal menggunakan aseton. Pengembangan sidik jari pada kertas termal menggunakan fuming iodin, ninhydrin, 1,8-diazofluoren-9-1 dan pdimetilaminosinamaldehid juga berhasil dilakukan ${ }^{[11]}$.

Untuk mengatasi hal ini tersebut, maka penelitian ini dilakukan dengan menggunakan serbuk alami baru dari daun Suji sebagai pengembangan sidik jari laten yang sederhana, tidak beracun, dan lebih murah dibandingkan dengan serbuk sidik jari yang digunakan secara komersial.

Suji merupakan tanaman yang sering digunakan sebagai pewarna makanan dan telah lama digunakan untuk obat ${ }^{[5]}$. Pewarna alami daun Suji adalah klorofil yaitu warna hijau. Daun Suji ini dipilih karena sumber klorofilnya dengan kandungan pigmen tinggi, ketersediaan, kemudahan panen/petik, dan pengeringan, mekanisme ekstraksi yang efisien, serta aktivitas enzim klorofilase yang rendah ${ }^{[12],[13] \text {. }}$

Klorofil hijau dapat berubah menjadi coklat akibat substitusi magnesium oleh hidrogen membentuk feofitin. Reaksi dapat berjalan lebih cepat pada larutan yang bersifat asam[13]. Salah satu tumbuhan yang banyak digunakan sebagai pewarna alami adalah daun Suji (Pleomele angustifolia). Daun Suji segar yang memiliki kadar air basis basah sebesar $73.25 \%$, mengandung 3773.9 ppm klorofil yang terdiri atas $2524.6 \mathrm{ppm}$ klorofil A dan 1250.3 ppm klorofil B[14],[15]. Klorofil hijau sangat mudah terdegradasi menjadi berwarna hijau muda sampai hijau kecoklatan ${ }^{[16]}$. 
Sifat fisik klorofil adalah menerima dan memantulkan sinar dengan menyerapnya pada panjang gelombang antara 400 hingga $700 \mathrm{~nm}$, terutama sinar merah dan biru. Sifat kimia klorofil antara lain: (i) tidak larut di dalam air, tetapi larut dalam pelarut organik yang lebih polar, seperti etanol dan kloroform, (ii) inti $\mathrm{Mg}$ akan tergeser oleh 2 atom $\mathrm{H}$ bila dalam suasana asam, sehingga (iii) membentuk suatu persenyawaan yang disebut feofitin yang berwarna coklat ${ }^{[13]}$.

Adapun kontribusi penelitian ini dalam sains termasuk kemudahan bahan yang digunakan dalam metode ini dapat ditemukan dalam kehidupan sehari-hari. Berdasarkan latar belakang diatas, maka dilakukan penelitian untuk mengembangkan sidik jari laten metode serbuk menggunakan daun Suji sebagai identifikasi sidik jari laten pada permukaan tidak berpori (kaca preparat, aluminium foil, CD) dan permukaan berpori (kertas HVS, kertas spektra, kertas karton). Penelitian ini menggunakan 90 sampel sidik jari berdasarkan golongan darah, jenis kelamin dan suku, yaitu Batak, Jawa dan Melayu.

\section{Metodologi Penelitian}

\section{Bahan kimia}

Bahan yang digunakan pada penelitian ini yaitu: daun Suji 500 g, kertas karton, kertas HVS, kertas spektra, kaca preparat, aluminium foil, $\mathrm{CD}, 10 \mathrm{ml}$ etil asetat dan $40 \mathrm{ml}$ petrolium eter.

\section{Peralatan}

Alat-alat yang digunakan dalam penelitian ini terdiri dari: ayakan dengan ukuran 60, 80, 100 dan 200 mesh), sendok, piring aluminium, wadah, oven, kaca arloji, gelas beaker, labu ukur, spatula, penggiling (blender), lifter dan sikat sidik jari.

\section{Prosedur penelitian}

\section{Pembuatan serbuk daun Suji}

Daun Suji segar sebanyak $500 \mathrm{~g}$ diambil dari pohon di Jalan Willem Iskandar, Medan. Daun Suji dicuci untuk memastikan debu dan kotoran lain yang menempel pada daun sudah bersih. Daun kemudian dikeringkan ke dalam oven, kemudian digiling sampai halus dengan menggunakan blender. Setelah itu, serbuk daun Suji diayak menggunakan ayakan ukuran 60, 80, 100 dan 200 mesh, yang dijadikan sebagai variable bebas untuk menentukan pengaruh ukuran partikel terhadap visualisasi sidik jari laten. Kemudian bubuk disimpan dalam wadah kedap udara pada suhu kamar ${ }^{[15]}$.

\section{Pengembangan sidik jari laten}

Pengembangan sidik jari laten dalam penelitian ini merupakan upaya untuk memperoleh visualisasi sidik jari. Cara mengembangkan sidik jari laten dengan metode serbuk pada permukaan yang tidak berpori (kaca preparat, aluminium foil, dan CD), yaitu dengan mengaplikasikan sidik jari yang sudah dioleskan serbuk daun Suji pada permukaan dengan cara memutar sikat diatas cetakan menggunakan pola melingkar sehingga cetak laten dapat tampak pada permukaan objeknya ${ }^{[17]}$.

Pengembangan sidik jari laten dengan metode serbuk pada permukaan berpori (kertas HVS, kertas spektra, dan kertas karton) yaitu dengan $50 \mathrm{mg}$ serbuk daun Suji dilarutkan dalam $10 \mathrm{~mL}$ etil asetat, kemudian dicampurkan dengan 40 $\mathrm{mL}$ petroleum eter. Jari-jari yang akan diambil sampel sidik jarinya terlebih dahulu disabun dan dicuci kemudian dikeringkan menggunakan tisu. Untuk mengumpulkan cetakan sebum, subjek diminta untuk menyentuh dahi atau wajah mereka untuk mendapatkan sebum di ujung jari mereka sehingga dapat diterapkan ke berbagai substrat/permukaan, satu cetakan untuk setiap permukaan. Hal ini dilakukan hingga muncul bentuk sidik jari yang tercetak. Sampel sidik jari dicelupkan ke dalam larutan tersebut, kemudian diangin-anginkan, lalu di oven selama 1 jam pada suhu $150^{\circ} \mathrm{C}[17],[18]$.

\section{Sampel sidik jari}

Sampel yang digunakan adalah 90 sidik jari mahasiswa UNIMED yang diambil secara purposive sampling berdasarkan berbagai suku, yaitu Jawa, Batak, Melayu. Selain itu juga pertimbangan pengambilan sampel adalah dengan mempertimbangkan golongan darah, 
dan jenis kelamin. Penelitian ini telah dilaksanakan pada bulan Juni hingga November 2020 di Laboratorium Kimia UNIMED dan Kepolisian Daerah (POLDA) Sumatra Utara.

\section{Hasil dan Diskusi}

\section{Pengembangan metode dusting serbuk daun Suji}

\section{Pengembangan sidik jari pada permukaan tidak berpori}

Serbuk daun Suji dipilih sebagai komponen serbuk pengenal sidik jari karena warna hijau yang berasal dari senyawa klorofil yang terkandung di dalamnya dan protein yang membentuk kompleks klorofil-protein ${ }^{[19]}$. Gambar 1 menunjukkan serbuk daun Suji dengan ukuran saringan yang bervariasi.

Hal ini sesuai dengan hasil yang diperoleh dari warna serbuk daun Suji yang menghasilkan warna hijau[17]. Serbuk ini dipengaruhi oleh beberapa ukuran atau ayakan, yaitu 60, 80, 100 dan 200 mesh. Kehalusan serbuk merupakan salah satu faktor penting dalam pembuatan serbuk karena semakin halus serbuk yang digunakan maka semakin baik kemampuan untuk melekat pada sidik jari laten dan semakin baik visualisasinya ${ }^{[2]}$.

Sidik jari yang mengandung sebum dicetak pada setiap media yang telah disediakan kemudian dikembangkan dengan metode serbuk daun Suji. Metode dusting dilakukan dengan cara memoleskan serbuk daun Suji secara merata pada permukaan tidak berpori yang mengandung sebum. Metode dusting merupakan metode fisik dari peningkatan cetakan laten dan bekerja secara mekanis terhadap partikel serbuk sidik jari ke komponen sebum yang terdapat pada punggungan kulit. Penerapan dari serbuk untuk mencetak dengan cara disikat merupakan teknik yang sederhana dan mudah, tetapi juga memiliki kelemahan, yaitu sikat yang bersentuhan dengan permukaan dapat menghancurkan cetakan sehingga karakteristik ridge dapat rusak.

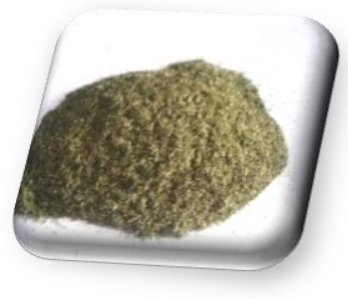

(a)

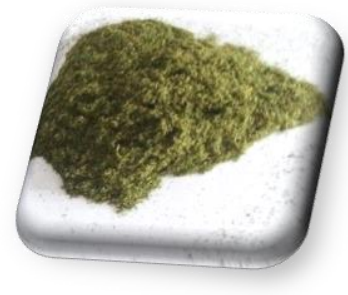

(b)

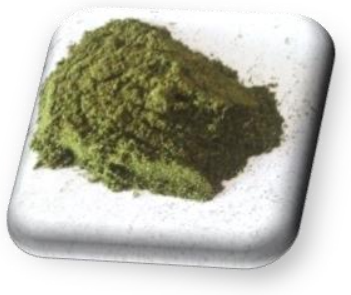

(c)

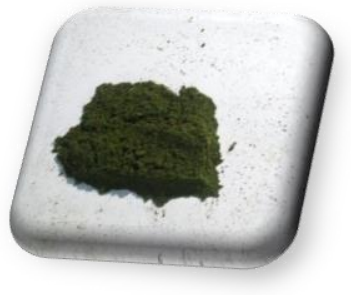

(d)

Gambar 1. Serbuk daun Suji dengan ukuran saringan: (a) 60, (b) 80, (c) 100, dan (d) 200 mesh.

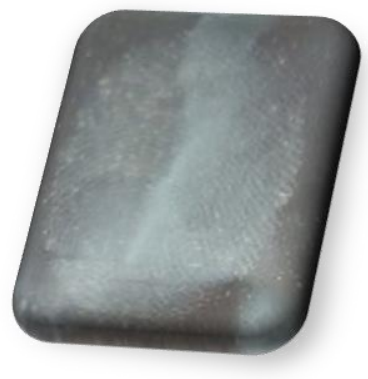

(a)

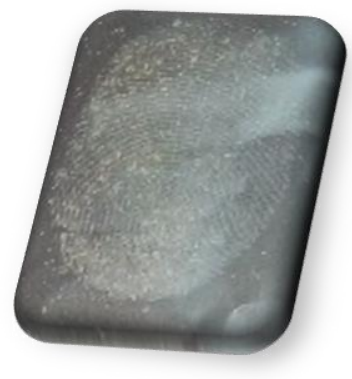

(b)

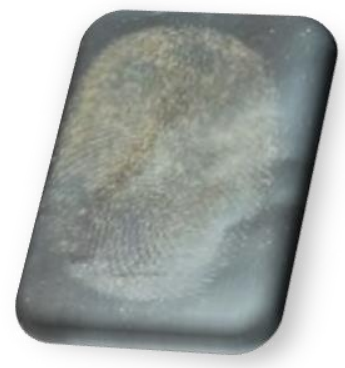

(c)

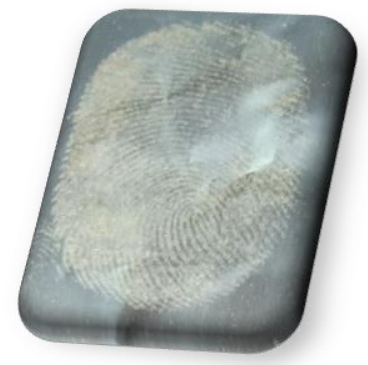

(d)

Gambar 2. Pengembangan sidik jari laten pada permukaan aluminium foil dengan ukuran serbuk (a) 60, (b) 80, (c) 100, dan (d) 200 mesh. 


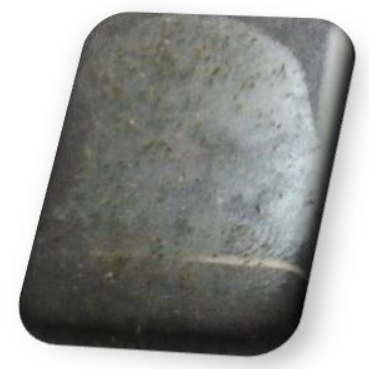

(a)

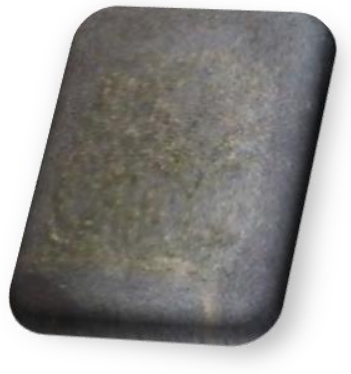

(b)

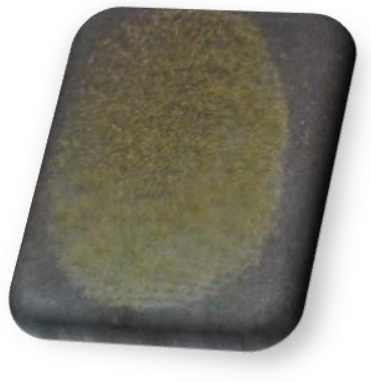

(c)

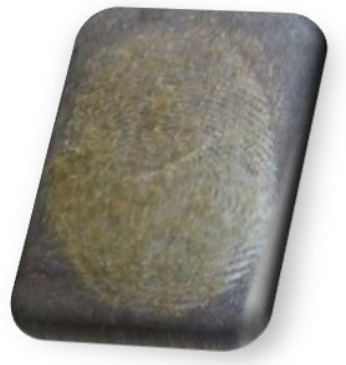

(d)

Gambar 3. Pengembangan sidik jari laten pada permukaan preparat kaca dengan ukuran serbuk (a) 60, (b) 80, (c) 100, (d) 200 mesh.

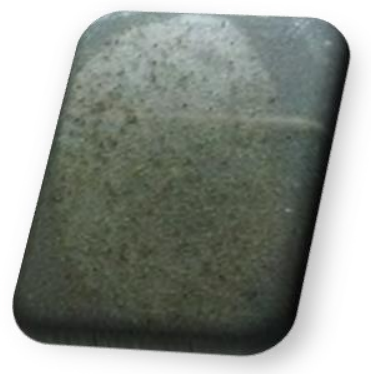

(a)

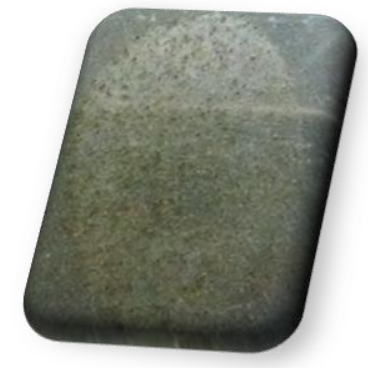

(b)

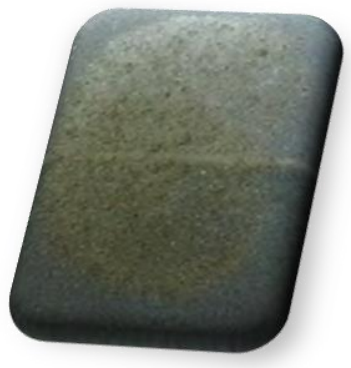

(c)

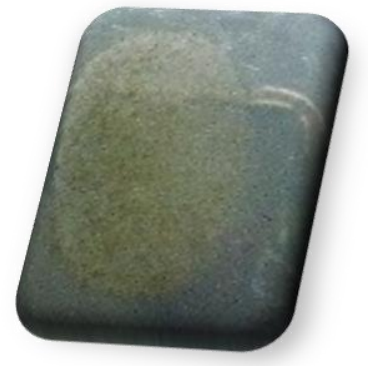

(d)

Gambar 4. Pengembangan sidik jari laten pada permukaan CD dengan ukuran serbuk: (a) 60, (b) 80, (c) 100, dan (d) 200 mesh.

Oleh karena itu, kelebihan serbuk pada permukaan dapat dihilangkan menggunakan kuas. Hal ini dilakukan hingga terlihat wujud dari bentuk sidik jari yang dicetak ${ }^{[18]}$. Pengembangan sidik jari laten pada permukaan aluminium foil, kaca preparat dan CD dapat dilihat pada Gambar 2, 3 dan 4.

Pengembangan sidik jari dengan serbuk didasarkan atas daya rekat serbuk dengan air yang terkandung dalam sidik jari laten tersebut. Serbuk hanya digunakan untuk mengembangkan sidik jari laten yang terdapat pada permukaan benda yang tidak menyerap keringat (tidak berpori) seperti kaca, porselin, permukaan yang dipernis/ plitur/dicat dan lainlain[3]. Serbuk daun Suji ukuran 60, 80, 100 dan
200 mesh pada permukaan aluminium foil, kaca preparat dan $\mathrm{CD}$ memberikan hasil kontras warna hijau.

Warna hijau daun Suji diduga karena adanya pigmen klorofil. Bubuk daun Suji dengan ukuran 60 dan 80 mesh visualisasi yang dihasilkan kurang bagus, karena pola sidik jari tidak dapat terlihat dengan jelas. Sedangkan ukuran partikel 100 dan 200 mesh pada permukaan aluminium foil dan preparat kaca memberikan hasil dengan kontras warna yang jelas dan pola sidik jari yang jelas dengan karakteristik ridge yang baik. Selain itu, hasil cetakan pada permukaan CD juga menunjukkan kurang bagus, sebab tingkat kesulitan untuk mencetak sidik jari pada media dengan 
permukaan yang halus dan silindris. Hal ini juga sejalan dengan penelitian perkembangan sidik jari, dimana visualisasi laten sidik jari tidak begitu jelas dikarenakan kurangnya sebum pada substrat dan permukaan substrat yang digunakan[6],[13],[19].

Kehalusan serbuk menjadi salah satu faktor penting dalam pembuatan serbuk karena semakin halus serbuk yang digunakan maka kemampuan melekatnya serbuk pada sidik jari laten makin baik dan visualisasinya semakin bagus ${ }^{[2]}$. Ukuran serbuk sangat mempengaruhi visualisasi dan pemelekatan serbuk. Semakin kecil ukuran serbuk yang digunakan, maka visualisasi serbuk menjadi lebih jelas dan proses penempelan serbuk menjadi lebih mudah. Semakin kecil ukuran partikel maka luas permukaan zat akan bertambah[18],[20]-[23]. Waktu pengujian sidik jari pada serbuk daun Suji bertahan hingga empat belas hari dengan menggunakan metode dusting. Lamanya kontras warna terhadap rentang waktu pengujian dipengaruhi oleh tersentuh atau tidaknya permukaan yang sudah mengandung sidik jari. Jika suatu permukaan tersentuh atau rusak, maka sidik jari akan perlahan-lahan mulai menghilang sehingga ciri-ciri lekukan (ridge) sidik jari tidak akan terlihat ${ }^{[4]}$. Pada jaringan tumbuhan, klorofil hadir dalam lamella organel antar sel yang disebut kloroplas. Keberadaannya dilindungi oleh protein yang membentuk kompleks klorofil-protein ${ }^{[12]}$. Metode pengabuan serbuk daun Suji terjadi karena reaksi yang terjadi antara klorofil A dan alanin dari keringat[24]-[26] seperti terlihat pada Gambar 5.
Penggunaan serbuk daun Suji dilakukan dengan cara menaburkan serbuk di atas permukaan benda yang terdapat sidik jari laten, dan setelah sidik jari laten muncul, maka sikat dipindahkan dengan hati-hati sesuai dengan garis papiler sidik jari, kemudian sidik jari dipindahkan pada lifter. Langkah selanjutnya adalah melakukan pengangkatan sidik jari laten. Metode pengangkatan sidik jari laten dengan lifter dilakukan dengan cara mengangkat sidik jari laten dengan terlebih dahulu meletakkan lifter di atas sidik jari laten yang telah ditaburi serbuk. Kemudian ditekan lurus dengan jari secara kuat, kemudian lifter diangkat dari permukaan dengan sekali tarik dan ditempelkan pada base card serta menghindari kemungkinan terjadinya gelembung udara[21],[22]. Hasil sidik jari laten menggunakan metode dusting serbuk daun Suji dengan lifter ditunjukkan pada Gambar 6 . Penelitian ini telah berhasil menghilangkan serbuk daun Suji menggunakan lifter dengan baik, menghasilkan visualisasi sidik jari yang baik pada lifter, karena warna yang kontras dari daun Suji hijau terlihat jelas. Daun Suji menghasilkan warna hijau yang berasal dari senyawa klorofil[17]. Warna hijau daun Suji diduga karena adanya pigmen klorofil[23].

\section{Pengembangan sidik jari pada permukaan berpori}

Pada pengembangan sidik jari laten pada permukaan berpori, serbuk daun Suji dilarutkan dengan etil asetat dan petroleum eter ${ }^{[24]}$. Gambar 7 menunjukkan reaksi klorofil A pada daun Suji ditambah etil asetat dan petroleum eter menghasilkan kloroasetat.
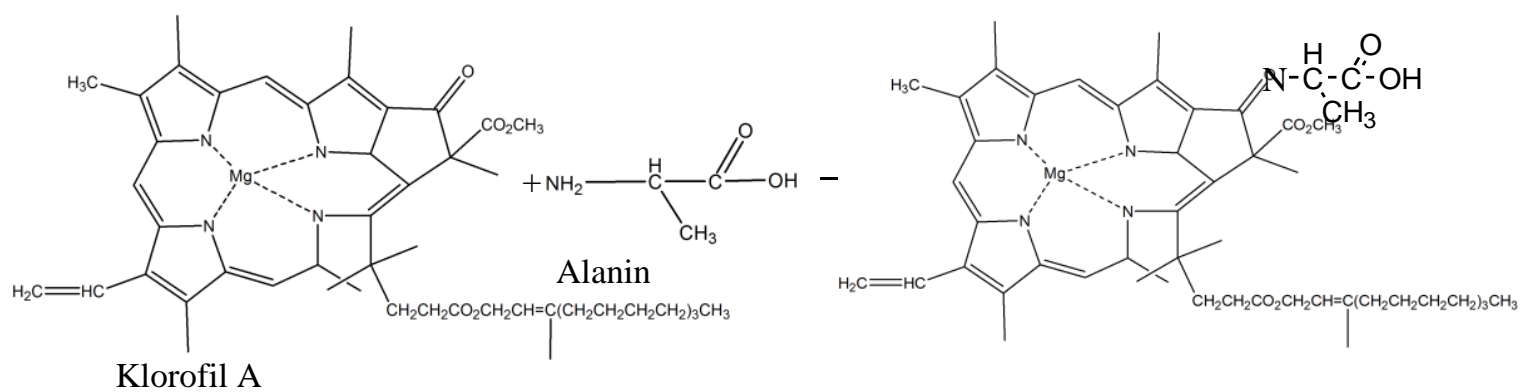

Gambar 5. Reaksi antara klorofil A dengan alanin dari keringat. 


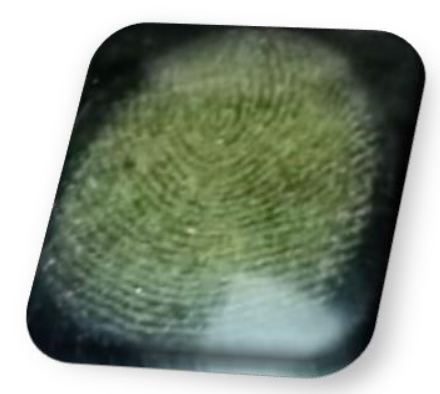

Gambar 6. Pengangkatan sidik jari laten metode dusting serbuk daun Suji dengan lifter.

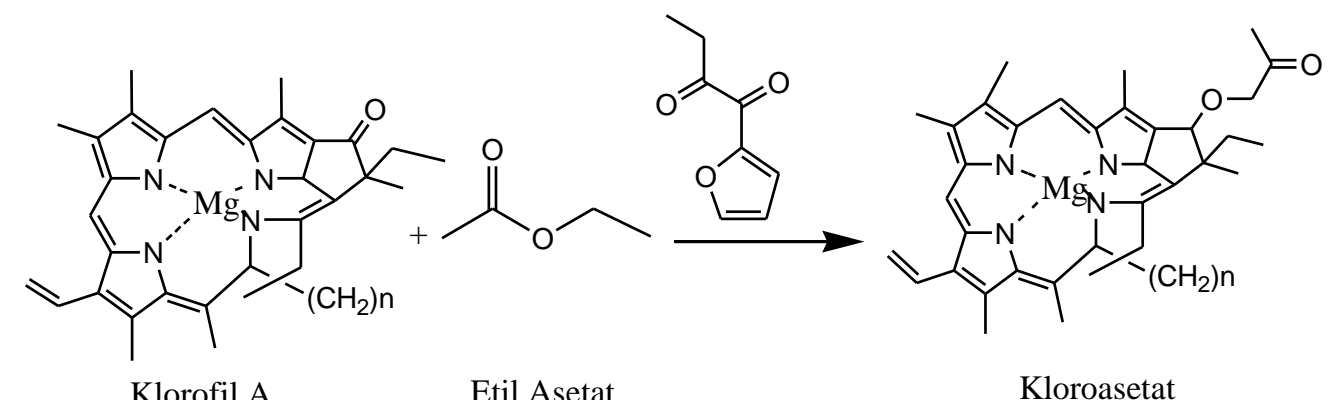

Gambar 7. Reaksi klorofil A dengan etil asetat dan petroleum.

Beberapa reagen membutuhkan waktu yang lama untuk reaksi berkembang atau munculnya warna pada kertas. Namun, semakin lama waktu kontak dengan sampel, semakin besar kemungkinan untuk menghilangkan fragmen sidik jari, dan tidak ada peningkatan yang signifikan pada pengembangan kertas ${ }^{[23]}$. Jadi, dibutuhkan reagen untuk mengembangkan dan memvisualisasikan sidik jari laten pada permukaan kertas untuk pemeriksaan forensik ${ }^{[25]}$. Hasil pengembangan sidik jari laten pada permukaan kertas HVS, karton, dan kertas spektral dapat dilihat pada Gambar 8 hingga 10.

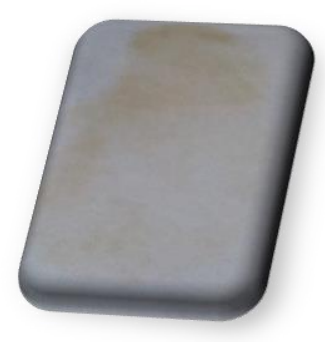

a)

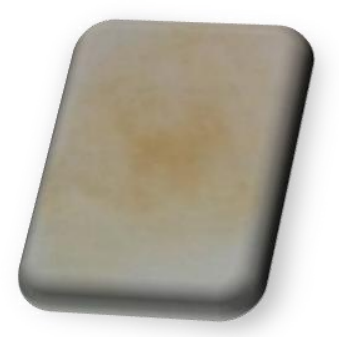

(b)

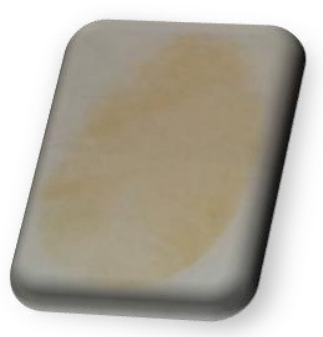

(c)

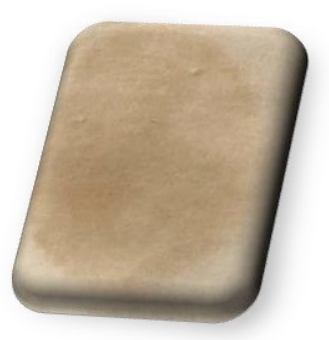

(d)

Gambar 8. Pengembangan sidik jari laten pada permukaan kertas HVS dengan ukuran serbuk: (a) 60, (b) 80, (c) 100, (d) 200 mesh. 


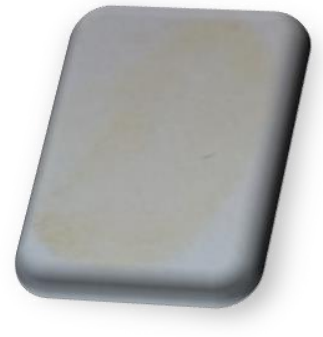

(a)

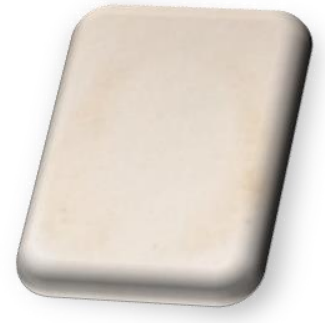

(b)

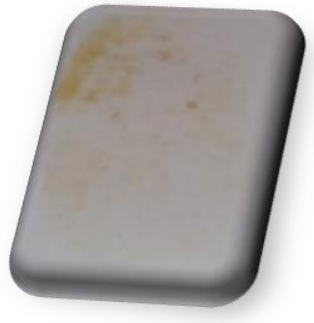

(c)

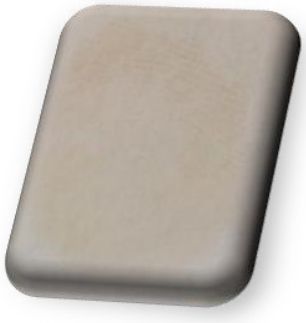

(d)

Gambar 9. Pengembangan sidik jari laten pada permukaan karton dengan ukuran serbuk: (a) 60, (b) 80, (c) 100, (d) 200 mesh.

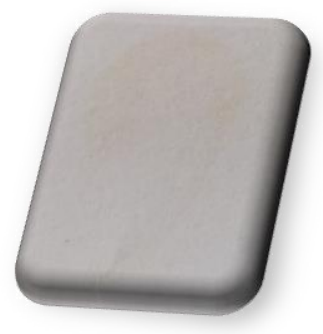

(a)

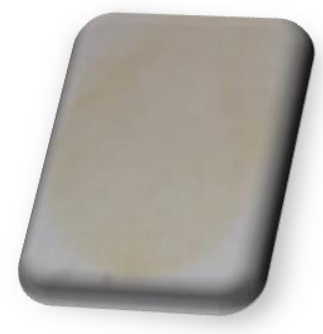

(b)

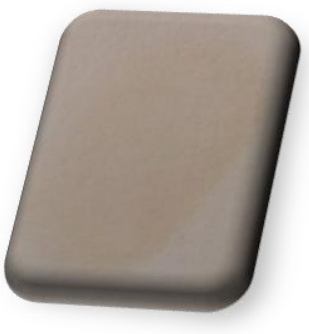

(c)

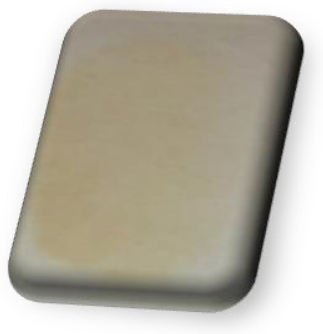

(d)

Gambar 10. Pengembangan sidik jari laten pada permukaan kertas spektral dengan ukuran serbuk (a) 60, (b) 80, (c) 100, dan (d) 200 mesh.

Pengembangan sidik jari laten digunakan pada permukaan benda yang menyerap keringat seperti kertas, karton kayu yang tidak dicat, karena sidik jari disini dapat digunakan atau dihilangkan dari permukaan kertas, sehingga mempengaruhi keaslian suatu dokumen ${ }^{[3]}$. Hasil pengembangan sidik jari pada permukaan kertas HVS, karton, dan kertas spektra menghasilkan visualisasi sidik jari yang kurang jelas. Bagian kertas yang terkena larutan akan berwarna coklat muda dan sidik jari biasanya berwarna coklat atau tidak terlihat. Perkembangan sidik jari laten pada permukaan kertas yang gagal atau tidak terlihat mungkin disebabkan karena kurangnya residu pada sidik jari dari sentuhan objek sebelum sampel sidik jari dikumpulkan ${ }^{[26]}$. Permukaan kertas menghasilkan warna coklat pada kertas HVS putih sehingga membentuk sidik jari[27]. Gambar
11 menunjukkan reaksi klorofil A pada daun Suji ditambah etil asetat dan petroleum eter menghasilkan kloroasetat. Reaksi kloroasetat ditambahkan dengan alanin untuk menghasilkan amina kloroasetat ${ }^{[22],[24] .}$

\section{Perbandingan pola sidik jari berdasarkan golongan darah, jenis kelamin dan etnis}

Identifikasi manusia adalah pengenalan individu berdasarkan beberapa karakteristik fisik yang unik bagi individu tersebut. Sidik jari bersifat konstan, individual dan membentuk kriteria yang paling dapat diandalkan untuk identifikasi. Golongan darah ABO-rhesus juga digunakan untuk mengidentifikasi seseorang, karena golongan darah merupakan sifat yang diturunkan. Persentase berdasarkan golongan darah ditunjukkan pada Gambar 12. 


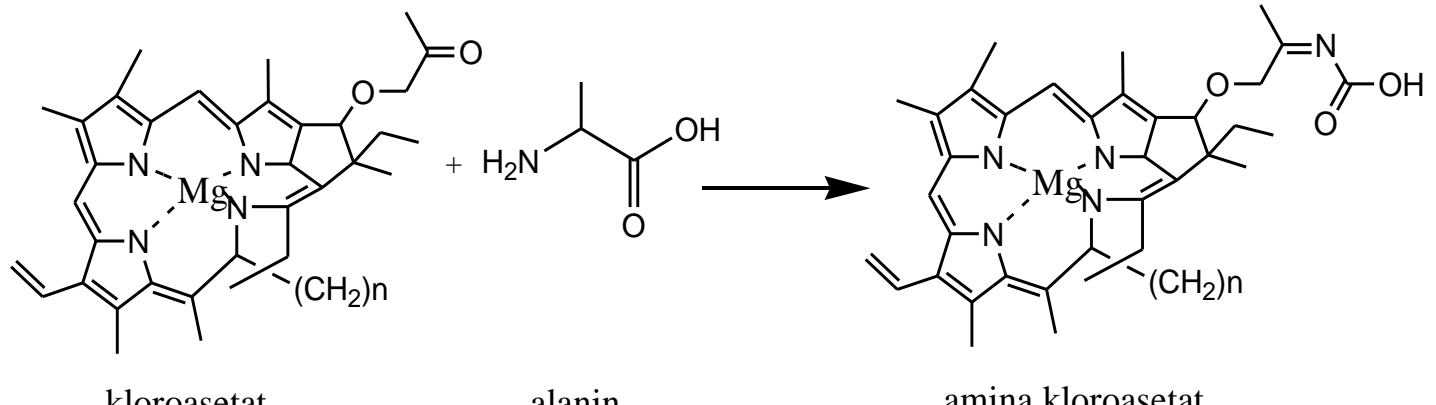

Gambar 11. Reaksi klorofil A dengan etil asetat dan petroleum ditambah alanin.

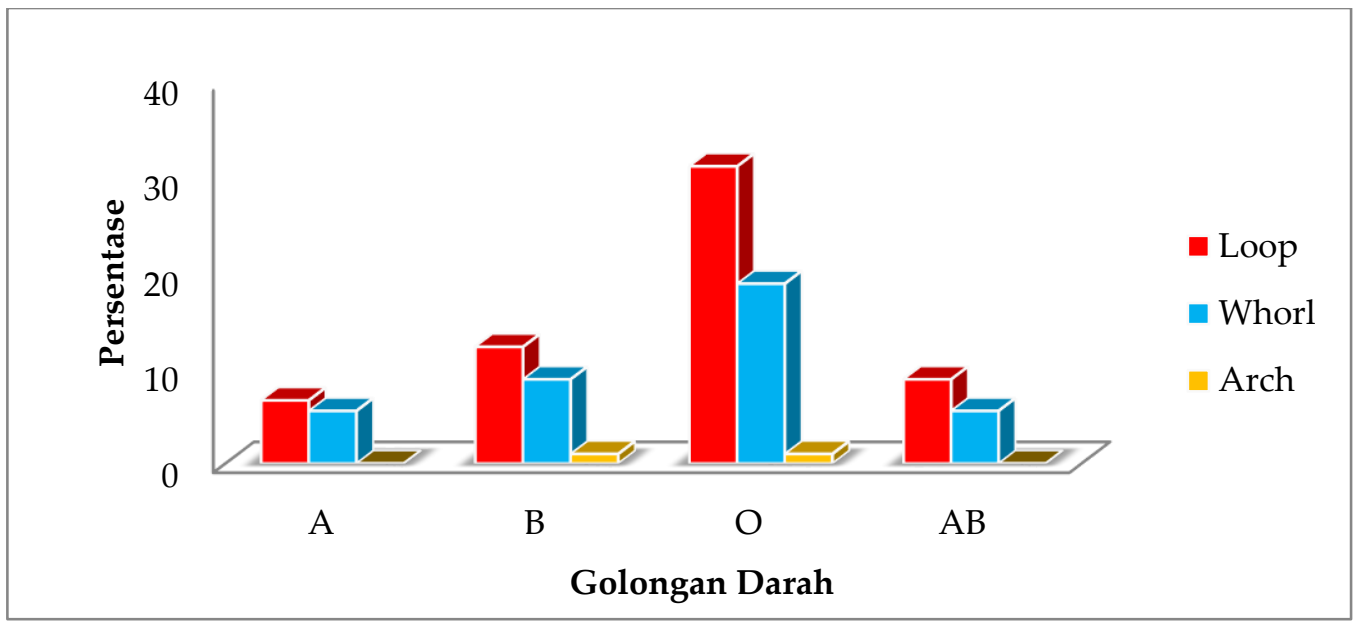

Gambar 12. Persentase pola sidik jari berdasarkan golongan darah.

Berdasarkan analisis pada Gambar 12 diperoleh bahwa dari 90 sampel, maka persentase tertinggi pada pola sidik jarinya adalah pola loop, dimana golongan darah $\mathrm{O} 31.1 ; \mathrm{B} 12.2 ; \mathrm{AB}$ 8.8; dan A 6.6 persen. Oleh karena itu, golongan darah yang dominan berada pada golongan darah $\mathrm{O}$ dan pola sidik jarinya adalah loop. Hasil penelitian ini sama dengan yang ditemukan bahwa golongan darah yang dominan pada pola loop adalah golongan darah $\mathrm{O}$ (55.9\%), disusul golongan darah A (22.4\%), golongan darah B $(20.4 \%)$ dan kemudian golongan darah golongan darah $\mathrm{AB}$ (1.2\%). Sama halnya dengan penelitian yang menemukan bahwa golongan darah yang dominan pada pola loop adalah golongan darah $\mathrm{O}$ sebanyak 36.28, golongan darah B sebanyak 33.48, disusul golongan darah A sebanyak 20.78 dan golongan darah AB sebanyak sebagai 9.47 persen[28]-[31]. Kemudian penelitian tentang hubungan sidik jari dengan golongan darah yaitu sebaran pola sidik jari pada golongan darah $\mathrm{A}, \mathrm{B}$, dan $\mathrm{O}$ ditemukan bahwa pola loop memiliki persentase tertinggi, kemudian whorl, dan arch. Ini berarti bahwa loop adalah pola sidik jari yang paling dominan dibandingkan dengan pola lainnya ${ }^{[32]-[34]}$.

Pola sidik jari merupakan variasi biologis yang berbeda antara satu suku dengan suku lainnya, antara perempuan dan laki-laki, bahkan pada kembar identik. Meskipun setiap individu menunjukkan pola sidik jari yang berbeda, 
namun sidik jari memiliki keteraturan yang dapat dengan mudah diidentifikasi karena frekuensi rata-rata setiap pola dan karakteristik lainnya menunjukkan variasi yang jelas antar populasi[30]. Variasi sidik jari pada populasi manusia digunakan untuk membandingkan pasien abnormal dengan kelompok normal berdasarkan jenis kelamin dan perbedaan, seperti yang ditunjukkan pada Gambar 13.

Berdasarkan hasil analisis pada Gambar 13 menunjukkan bahwa berdasarkan jenis kelamin, sampel yang terdiri dari 90 orang terdiri dari 18 (19.9\%) laki-laki dan 72 (81.1\%) perempuan. Persentase tertinggi pada pola sidik jari loop perempuan sebanyak $45.5 \%$ dan laki-laki sebanyak 13.3\%. Hal ini sesuai dengan hasil penelitian yang menemukan pola sidik jari loop tertinggi adalah perempuan, diikuti oleh pola sidik jari loop laki-laki[35]. Pola sidik jari memiliki persentase loop tertinggi, diikuti oleh whorl, lalu arch. Sementara itu, penelitian ini mengungkapkan bahwa pola arch adalah yang paling sederhana dan juga paling langka ditemukan dan pola loop adalah pola yang paling umum ${ }^{[30]}$.

Persentase berdasarkan suku ditunjukkan pada Gambar 14. Karakter lain yang dapat digunakan untuk mengkonfirmasi sidik jari adalah suku ${ }^{[25]}$ seperti ditunjukkan pada Gambar 14.

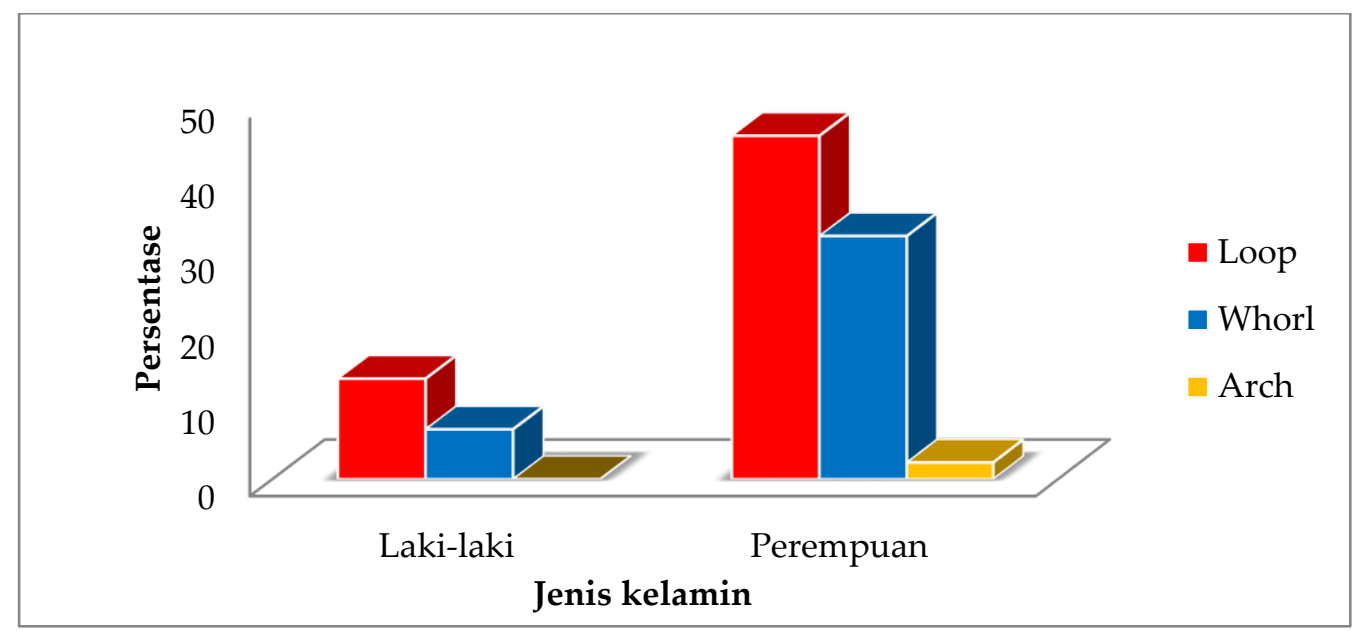

Gambar 13. Persentase pola sidik jari berdasarkan jenis kelamin.

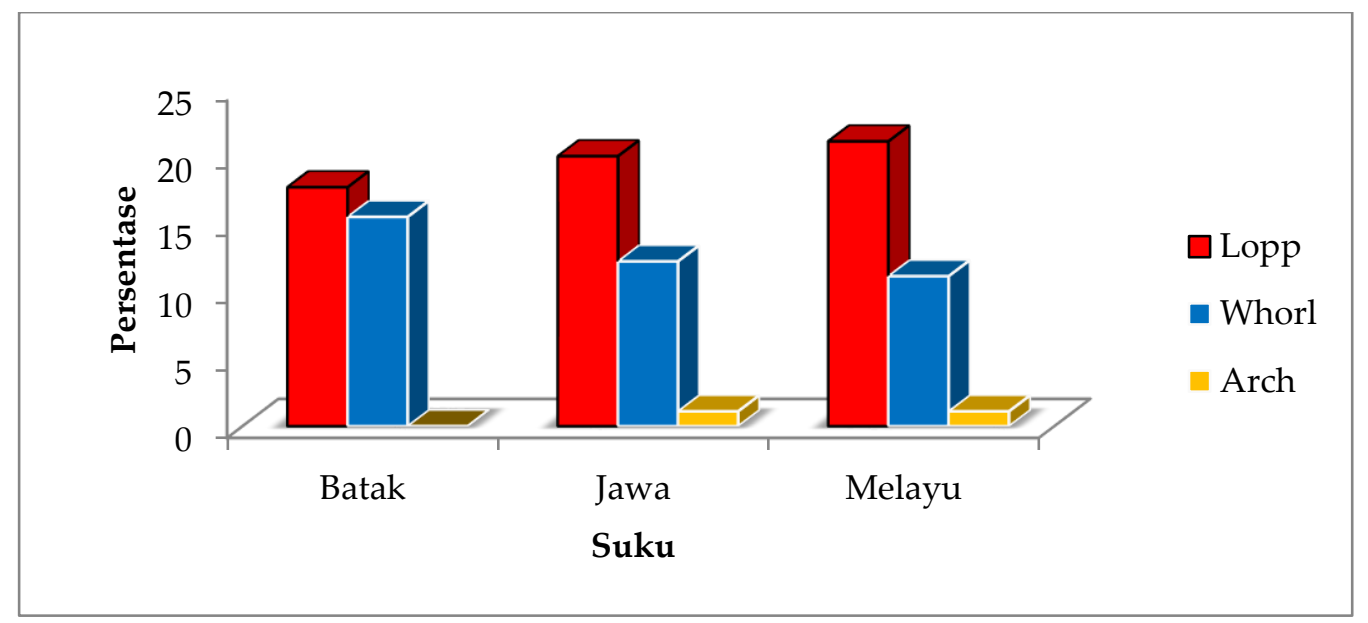

Gambar 14. Persentase pola sidik jari berdasarkan suku. 
Hal ini sama dengan penelitian yang menemukan bahwa pola sidik jari yang tertinggi adalah pola sidik jari loop kemudian whorl dan arch[36]. Penelitian yang lain juga menemukan bahwa pola sidik jari yang dominan adalah pola sidik jari loop ${ }^{[30]}$. Kemudian, penelitian ini menyatakan bahwa sampel suku jawa banyak dijumpai pola loop lalu selanjutnya pola whorl[28]. Sedangkan data hasil penelitian yang lain juga memperoleh persentase tertinggi suku jawa adalah pola loop dibandingkan dengan suku batak[37].

Berdasarkan Gambar 14, telah ditemukan bahwa persentase tertinggi dari pola sidik jari loop adalah 21.1 untuk Melayu, 20 untuk Jawa, dan 17.7 persen untuk Batak. Namun, pola sidik jari whorl itu adalah 15.5 untuk Batak, 12.2 untuk Jawa, dan 11.1 untuk Melayu. Hal ini sama dengan penelitian yang menemukan bahwa pola sidik jari tertinggi adalah pola sidik jari loop, kemudian whorl dan arch. Pola sidik jari yang dominan adalah pola sidik jari loop. Kemudian, penelitian ini menyatakan bahwa sampel suku Jawa banyak ditemukan pola loop dan kemudian pola whorl. Persentase tertinggi suku Jawa adalah pola loop dibandingkan suku Batak[36]-[38].

\section{Kesimpulan}

Berdasarkan beberapa temuan di atas, maka dapat ditarik beberapa kesimpulan sebagai berikut:

1. Daun Suji dapat digunakan sebagai bahan visualisasi sidik jari laten. Hasil pengembangan sidik jari laten permukaan tidak berpori berhasil dilakukan dengan menggunakan metode dusting serbuk daun Suji. Sedangkan pengembangan pada permukaan berpori hasil yang diperoleh kurang berhasil karena pola sidik jari tidak dapat terlihat dengan jelas.

2. Hasil perbandingan visualisasi sidik jari laten menggunakan metode dusting memberikan kontras warna pada permukaan serbuk daun Suji yang tidak berpori, berwarna hijau, sedangkan permukaan yang berpori berwarna coklat.
3. Pengaruh ayakan atau ukuran partikel menunjukkan bahwa ukuran serbuk daun Suji 100 dan 200 mesh pada permukaan aluminium foil dan preparat kaca memberikan kontras warna yang jelas. Sedangkan ukuran serbuk 60 dan 80 mesh visualisasi yang dihasilkan kurang maksimal, dimana sidik jari tidak tercetak dengan baik.

\section{Ucapan Terima Kasih}

Penulis mengucapkan terima kasih kepada semua pihak yang telah berpartisipasi menjadi sampel dalam penelitian ini. Terima kasih juga kepada Laboratorium Kimia FMIPA Universitas Negeri Medan, dan Laboratorium Forensik POLDA Sumatra Utara.

\section{Daftar Pustaka}

1. Batti, K. M., Penggunaan sidik jari sebagai alat bukti untuk mengungkap tindak pidana pencurian dengan kekerasan. Lex Soc., 5(6): 21-28 (2017).

2. Elishian, C. \& Ketrin, R., Pengembangan material serbuk silika untuk identifikasi sidik jari. J. Kim. Terap. Indones., 13(1): 35-50 (2011).

3. Yuserlina, A., Peranan sidik jari dalam proses penyidikan untuk menentukan pelaku tindak pidana. J. Cendekia Huk., 3(1): 46-60 (2017).

4. Sari, S. A., Jasmidi., Kembaren, A. \& Ilmi, A. N., Development of eco-friendly fingerprint visualization using herb. Asian J. Chem., 31(11): 2601-2606 (2019).

5. Sari, S. A., Ningsih, H., Jasmidi., Kembaren, A. \& Mahat, N. A., Development of gambir powder as a cheap and green fingerprint powder for forensic applications. in AIP Conference Proceedings, 2155: 020023 (2019).

6. Sari, S. A., Sinaga, Y., Jasmidi., Mahmud. \& Juwitaningsih, T., A new laten fingerprint method using natural powder purple sweet potato (Ipomoea batatas L. Poiret). in The Eight National Symposium \& The Fourth International Symposium. Bangkokthornburi University., 329-343 (2020). 
7. Thakur, P. \& Garg, R. K., New developing reagent for latent fingermark visualization: Fuller's earth (Multani Mitti). Egypt. J. Forensic Sci., 6(4): 449-458 (2016).

8. Garg, R. K., Kumari, H. \& Kaur, R., A new technique for visualization of latent fingerprints on various surfaces using powder from turmeric: A rhizomatous herbaceous plant (Curcuma longa). Egypt. J. Forensic Sci., 1(1): 53-57 (2011).

9. Datta, A. K., Lee, H. C., Ramotowski, R. \& Gaensslen, R. E., Advances in Fingerprint Technology. CRC Press, (2001).

10. Prasad, V., Prasad, L., Lukose, S. \& Agarwal, P., Latent fingerprint development by using silver nanoparticles and silver nitrate-a comparative study. J. Forensic Sci., 66(3): 1065-1074 (2021).

11. Yadav, P. K., Development of fingerprints on thermal papers-a review. Egypt. J. Forensic Sci., 9(47): 1-8 (2019).

12. Sekar, M. \& Zulkifli, N. F., Development of natural latent fingerprint powder from durian seeds-a green and effective approach in crime scene. Indo Am. J. Pharm. Sci., 4(8): 2362-2367 (2017).

13. Tama., Bisma, J., Kumalaningsih, S. \& Mulyadi, F. A., Studi pembuatan bubuk pewarna alami dari daun suji (Pleomele angustifolia NE Br.). kajian konsentrasi maltodekstrin dan $\mathrm{MgCO}$. Industria, 3(2): 73-82 (2014).

14. Tran, Q. Le., Tezuka, Y., Banskota, A. H., Tran, Q. K., Saiki, I. \& Kadota, S., New spirostanol steroids and steroidal saponins from roots and rhizomes of Dracaena angustifolia and their antiproliferative activity. J. Nat. Prod., 64(9): 1127-1132 (2001).

15. Aryanti., Nita., Nafiunisa, A. \& Willis, F. M., Ekstraksi dan karakterisasi klorofil dari daun suji (Pleomele angustifolia) sebagai pewarna pangan alami. J. Apl. Teknol. Pangan, 5(4): 129-135 (2016).

16. Comunian, T. A., Monterrey-Quintero, E. S., Thomazini, M., Balieiro, J. C. C., Piccone, P., Pittia, P. \& Favaro-Trindade, C. S., Assessment of production efficiency, physicochemical properties and storage stability of spray-dried chlorophyllide, a natural food colourant, using gum Arabic, maltodextrin and soy protein isolate-based carrier systems. Int. J. Food Sci. Technol., 46(6): 1259-1265 (2011).

17. Indrasti, D., Andarwulan, N., Hari Purnomo, E. \& Wulandari, N., Klorofil daun Suji: potensi dan tantangan pengembangan pewarna hijau alami. J. Ilmu Pertan. Indones., 24(2): 109-116 (2019).

18. Thomas, P. \& Farrugia, K., An investigation into the enhancement of fingermarks in blood on paper with genipin and lawsone. Sci. Justice, 53(3): 315-320 (2013).

19. Miazek, K. \& Ledakowicz, S., Chlorophyll extraction from leaves, needles and microalgae: a kinetic approach. Int. J. Agric. Biol. Eng., 6(2): 107-115 (2013).

20. Rohatgi, R. \& Kapoor, A. K., New visualizing agents for developing latent fingerprints on various porous and nonporous surfaces using different household food items. Asian J. Sci. Appl. Technol., 3(2): 33-38 (2014).

21. Singh, K., Sharma, S. \& Garg, R. K., Visualization of latent fingerprints using silica gel G: a new technique. Egypt. J. Forensic Sci., 3(1): 20-25 (2013).

22. Tambun, R., Limbong, H. P., Pinem, C. \& Manurung, E., Pengaruh ukuran partikel, waktu dan suhu pada ekstraksi fenol dari lengkuas merah. J. Tek. Kim. USU, 5(4): 5356 (2017).

23. Rawn, J. D. \& Ouellette, R. J., Organic chemistry: structure, mechanism, synthesis. Academic Press, (2018).

24. Noviantari, N. P., Suhendra, L. \& Wartini, N. M., Pengaruh ukuran partikel bubuk dan konsentrasi pelarut aseton terhadap karakteristik ekstrak warna Sargassum polycystum. J. Rekayasa dan Manaj. Agroindustri, 5(3): 102-112 (2017).

25. Perdana, A. S. W., Kajian implementasi kewenangan penyidik POLRI untuk melakukan pengambilan sidik jari dengan teknik daktiloskopi dalam pengungkapan perkara pidana di Kepolisian Resort 
Sukoharjo. Universitas Sebelas Maret, (2011).

26. Fritz, P., van Bronswijk, W. \& Lewis, S. W., p-Dimethylaminobenzaldehyde:

preliminary investigations into a novel reagent for the detection of latent fingermarks on paper surfaces. Anal. Methods, 5(13): 3207 (2013).

27. Zhao, Y., Feng, Y. \& Luo, Y., Improvement in latent fingermark detection on thermal paper using 5,6-dimethoxy-1,2indandione/PVP. J. Forensic Sci. Criminol., 1(2): 1-4 (2013).

28. Jelly, R., Lewis, S. W., Lennard, C., Lim, K. F. \& Almog, J., Lawsone: a novel reagent for the detection of latent fingermarks on paper surfaces. Chem. Commun., 30(30): 3513 (2008).

29. Raihanun, S., Mentari, D., Wulandari, M. \& Pebrina, R., Description of ABO-rhesus blood group and fingerprint patterns students D-3 Teknologi Transfusi Darah of STIKES Guna Bangsa Yogyakarta. J. Heal., 6(2): 105-111 (2019).

30. Sahu, M., Tiwari, A. \& Rao, I. A., Distribution of fingerprint patterns in different ABO blood groups. J. Res. Emerg. Sci. Technol., 3(6): 94-100 (2016).

31. Patil, A., Malik, A. \& Shirole, T., Fingerprint patterns in relation to gender and blood groups-a study in Navi Mumbai. Indian J. Forensic Community Med., 4(3): 204-208 (2017).
32. Eboh, D. E. O., Fingerprint patterns in relation to gender and blood group among students of Delta State University, Abraka, Nigeria. J. Exp. Clin. Anat., 12(2): 82 (2013).

33. Sodhi, G. S. \& Kaur, J., Fingerprint powder formulation based on Azure II dye. Def. Sci. J., 54(2): 179-182 (2004).

34. Downham, R. P., Mehmet, S. \& Sears, V. G., A pseudo-operational investigation into the development of latent fingerprints on flexible plastic packaging films. J. Forensic Identif., 62(6): 661-682 (2012).

35. LaFratta, C. N., Huh, S. P., Mallillin, A. C., Riviello, P. J. \& Walt, D. R., Visualizing fluorescence: using a homemade fluorescence 'microscope' to view latent fingerprints on paper. J. Chem. Educ., 87(10): 1105-1107 (2010).

36. Sufitni., Pola sidik jari pada kelompok retardasi mental dan kelompok normal. Maj. Kedokt. Nusant., 40(3): 180-190 (2007).

37. Purbasari, K. \& Sumadji, A. R., Variasi pola sidik jari mahasiswa berbagai suku bangsa di Kota Madiun. J. Florea, 4(2): 47-54 (2017).

38. Hidayati, F., Variasi pola sidik jari pada populasi Jawa dan Papua. AntroUnairdotNet, 4(1): 30-41 (2015). 